\title{
ELLIPSE AND OVAL IN BAROQUE SACRAL ARCHITECTURE IN SLOVAKIA
}

\author{
Zuzana GRÚŇOVÁ ${ }^{1 *}$, Michaela HOLEŠOVÁ ${ }^{2}$ \\ ${ }^{1}$ Department of Building Engineering and Urban Planning, Faculty of Civil Engineering, University of \\ Žilina, Univerzitná 8215/1, 01026 Zilina, Slovakia. \\ ${ }^{2}$ Department of Structural Mechanics and Applied Mathematics, Faculty of Civil Engineering, \\ University of Žilina, Univerzitná 8215/1, 01026 Žilina, Slovakia. \\ corresponding author: zuzana.grunova@fstav.uniza.sk.
}

\section{Abstract}

Oval, circular and elliptic forms appear in the architecture from the very beginning. The basic problem of the geometric analysis of the spaces with an elliptic or oval ground plan is a great sensitivity of the outcome calculations to the plan's precision, mainly to distinguish between oval and ellipse. Sebastiano Serlio and Guarino Guarini belong to those architects, theoreticians, who analysed the potential of circular or oval forms and some of their ideas are analysed in the paper. Elliptical or oval plans were used also in Slovak baroque architecture or interior elements and the paper introduce some of the most known examples as a connection to the world architecture ideas.
\end{abstract}

\section{Keywords:}

Elliptic and oval plans; Slovak baroque sacral architecture; Geometrical analysis of Serlio's and Guarini's ovals.

\section{Introduction}

Oval and elliptic forms belonged to architectural dictionary of forms from the very beginning. The basic shape, easy to construct was of course a circle. Circular or many forms of circular-like, not precisely shaped forms could be found at many Neolithic sites like Skara Brae (profane and supposed sacral spaces), temples of Malta and many others. Some other examples of the earliest structures are also presented in [1]. Cultures of Aegean Sea used circular plan for their heroons, tholoi. Ancient Greeks and Romans had also effective use for acoustic properties of circular forms in design of theatres or meeting halls. Monumental Pantheon in Rome is colossal example of circle - sphere used to shape a sacral space.

Aegean cultures used constructions of a circular plan for their heroons or shaft grave circles, accompanied with tholoi - tombs of circular plan, shaped as a beehive. The most famous examples are Mycenae grave circle A and B. Ancient Greece and Rome used the shape of a circle and its great acoustic possibilities - for theatres, also for some parts of public meeting buildings. Circular shape was used in sacral buildings Tholoi on circular temples (e.g. The Temple of Vesta at the Forum Romanum) and the most famous representative is the Pantheon with colossal vault. Elliptical shapes with various types of precision were used by builders constructing arenas. Archaeologists and mathematicians have produced an impressive number of publications in which they tried to analyse the shapes of arenas, but the question whether the "true" ellipse or polycentric structure by circular sectors is not yet clear - the statistical discrepancies for both curves show significant differences [2, 3, 4]. Also there was always a question of practical issues - seems that smaller arenas could be build using "gardener construction" method of a true ellipse, later, great arenas are maybe more probably ovals, easier to construct and more practical for the need of many parallel curves/arches.

The basic problem of the geometric analysis of the spaces with an elliptic or oval ground plan, essentially analysis of all architectural spaces is a great sensitivity of the outcome calculations to the plan's precision. If there is no exact measurement (costly 3D scan), outcome is only more or less accurate speculation that the created geometric procedure or construction is the one the builder probably used. When the documents are only schematic, the geometry of the plan can be only deduced in the relationship of period known conventional method of construction. Variations between different geometrical constructions are sometimes insignificant or not significant enough to be differentiated with decisive certainty. Sometimes analysis can be supported by analysis of static scheme or load bearing architectural features. Sometime non-load bearing members are significant 
ones; they create a rhythm of the building, visual impact (pilasters, cornices, ornaments). These elements are often placed at the intersections of major axes, in crossing points of the space geometric design.

Despite these problems, it seems that just the various ovals' constructions, based on the square; circle or triangle network has been preferred in the history of architecture. Perhaps the main reason is in particular their relative ease of constructing with the aid of the circles (pin, line at a building site) and the known, the established procedures (equilateral triangle, the right 3-4-5 triangle). Oval is a practical design, unlike true ellipse is. Oval is suitable for the needs of the construction work right, framing and monitoring, for example, the proper course of masonry walls and vaults.

\section{Medieval geometric constructions connected to symbolic meaning}

Medieval buildings - namely gothic - were precisely based on symbolical meaning, expressed in a geometric construction. "Medieval design methods were based on a compass and ruler geometry, with no concern for rational and irrational proportions." [5].

Circle, square and equilateral triangle were the most used basis for extent, complex constructions of the tracery, sculptural programme of the building and of course for the plan, section; therefore space of the architectonical design. Central disposition of the former periods remained present in rounded rotundas. Complex study of Romanesque churches in the south of France was made by Chappuis in 1976 [6]. Clear attempts to construct oval or mandorla shaped domes preceded mostly cited renaissance works Fig. 1.

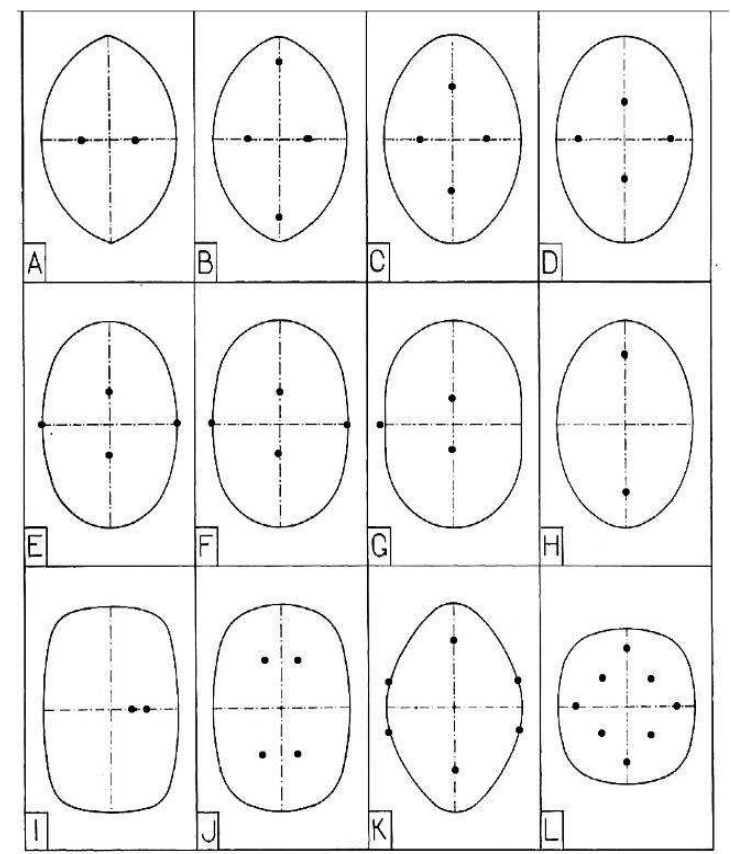

Fig. 1: Oval shaped cupolas and vaults of the Romanesque churches of the south France. Source: [6].

Intersection of two circles was the first and the most simple of constructions on the path to the ovals. In the architecture, it was necessary to adapt radii or distance between the centres of the circles according to the rhythm of the vaults or distance between load bearing elements. Mandorla or Vesica Piscis was the most clear and the oldest form of such an intersection of two circles.

Mandorla (almond in Italian) or Vesica piscis (the bladder of the fish in Latin) was not originally a Christian symbol. It was known from many ancient religions as a type of gloriole, a way to represent radiation of the spiritual energy, the most saint space surrounding the God, Saint or Buddha. Mandorla shape also appeared in the Islamic architecture motifs. It was a symbol of the beginning in the ancient connotation, connected to anatomical shapes of woman genitals. 

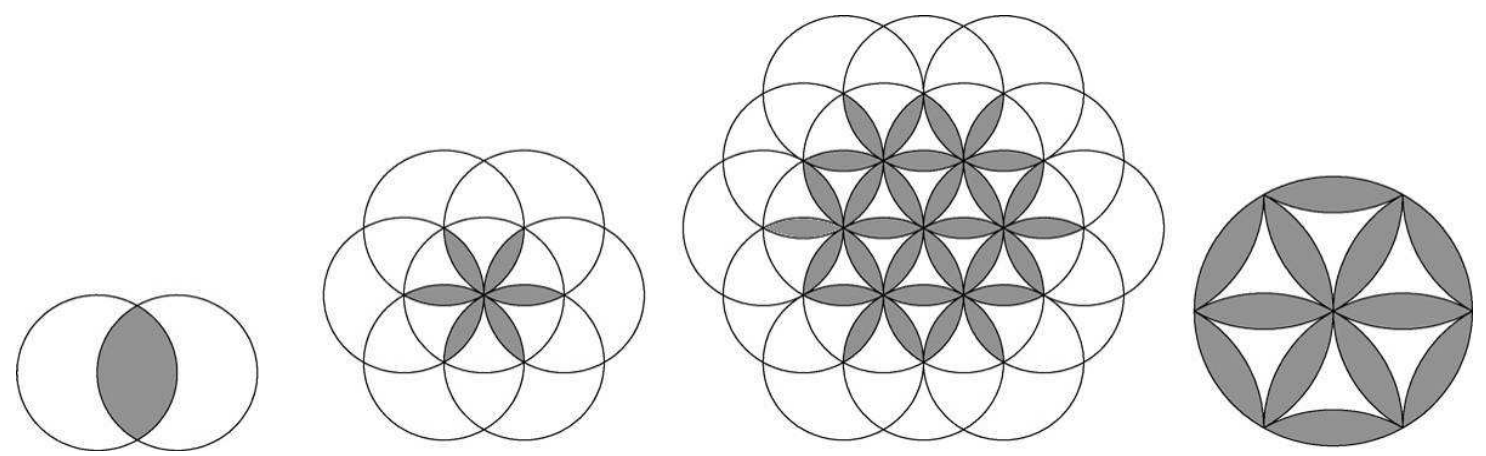

Fig. 2: From the left: Vesica Piscis, The seed of Life, the Flower of Life, and Slavic solar sign. Drawing by Grúňová, 2016.

The system of the intersecting circles (Vesica shape also) was contained in related symbols known as the Seed of life and The Flower of life, Fig. 2. These symbols were known to ancient Egypt. In the Slavic regions this symbol was used as a solar sign, related to rebirth of life in the cycle of seasons. Sometime it is interpreted as a symbol of Slavic god Perun. There are many occurrences of this solar rosette sign also in the Slovak folk architecture - they used to be carved into wooden portals or wooden ceiling beams or used simply as a surface ornament.

Vesica was used as an algebraic geometry problem in the Stoicheia Algebras (Elements of Algebra) by Euclidus (Alexandria, the 3rd century B. C.). Upper and lower limit of numerical expression of the square root was also accepted by Archimedes.

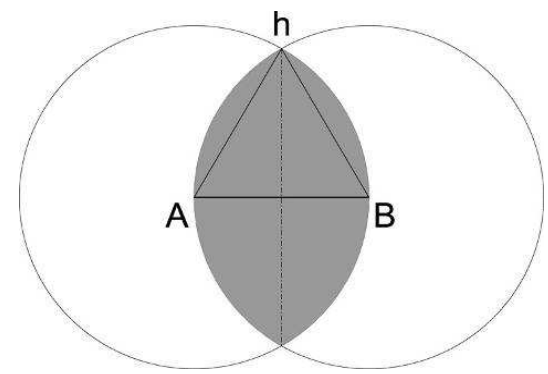

Fig. 3: Redrawn Vesica diagram from Euclidus Elements. Source: [7, 8].

Euclidus [7, 8] used Vesica form geometric construction of square root of 3 in the mandorla, Fig. 3. Here $h: A B=\sqrt{3}$, while $h$ is the height of intersection and $\mathrm{AB}$ is the line connecting the centres of circles.

Christian symbology connected mandorla - in the more naturalistic view - with meanings such as birth; Christ could be viewed in mandorla as a child in a mother's womb. Sometimes this iconography was used as a pendant of Ascension, connected as a birth of life and death with spiritual enlightening, the beginning and the end. More occurrences were more shifted in the meaning to the symbol of spiritual energy and sanctity. Christ Blessing, included in mandorla with 4 apostles, Transfiguration of Christ in mandorla or Ascension scenes are examples to that meaning. For more information on mandorla, see [8] and [9]. 

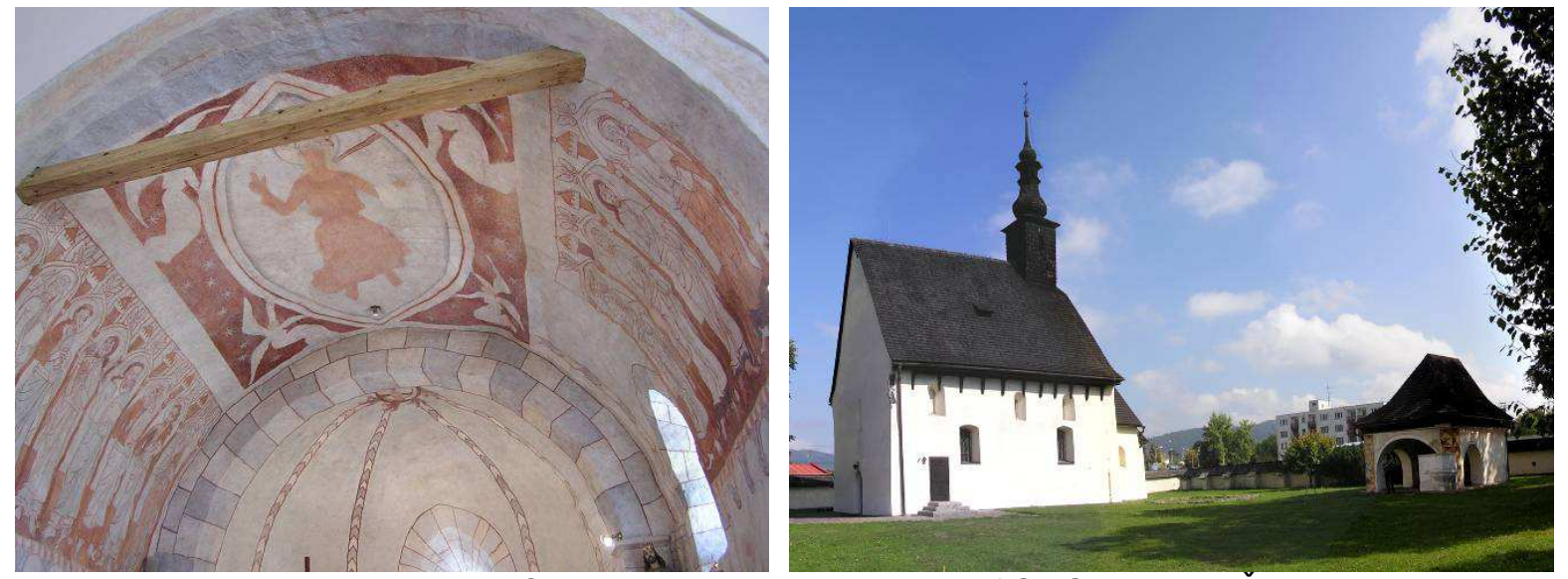

Fig. 4: Mandorla with Blessing Christ in the medieval church of St. Stephan in Žilina. Late roman church is the oldest monument in Žilina, built at the beginning of the 11th century (precise years 1018 and 1025 are also mentioned). Photos by Grúňová, 2013.

Symbol and construction of geometry in mandorla is used in gothic pointed arch. This symbol was considered too naturalistic and its appearance in the connection with symbolic meaning in architecture or art is disappearing in the renaissance period.

\section{Renaissance forms that favour ovals and complexity of baroque architecture}

Renaissance theories (main source is Vitruvius as available connection to the ancient theory and practice in the architecture) emphasized the idea of circle or central space as a symbol of God; symbol of completeness and perfection. L. B. Alberti: "... nature itself likes the circular things...", Francesco di Georgio: "Circle is the symbol of God's Sanctity and it should be in the centre of the Church..", Sebastiano Serlio: "Circle is more perfect than all of the other forms" [11].

Sebastiano Serlio in one of his theoretic books Libro Primo (1566) submitted an explanation for several renaissance geometric constructions. The most of them were of course in relation to the rapid evolvement of perspective drawing and constructions, but 4 of them are dedicated to the most common (in Serlio's opinion), often used constructions of polycentric ovals, Fig. 5 [12]. Basis for the construction was a circle, square, equilateral or isosceles triangle. Equilateral triangle was considered as a perfect triangle and it was easy to construct using compass or rope and poles. Construction (Fig. $5 \mathrm{~d}$ ) was de facto mandorla - Vesica piscis. All constructions b, c, and d were from architect point of view rather rigid in practical use, only Fig. 5 a) could be applied to various plans, on various proportions of height to length or sides of a plan to height in section.
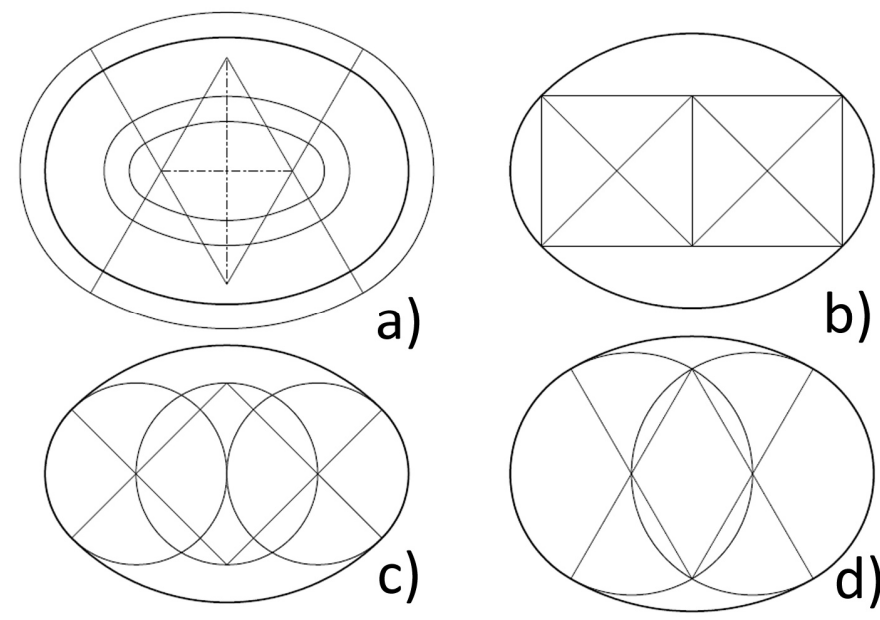

a)

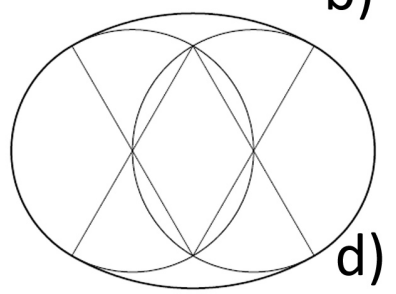

Fig. 5: Oval constructions by Serlio. Source: [12]. Redrawn by Grúňová. 

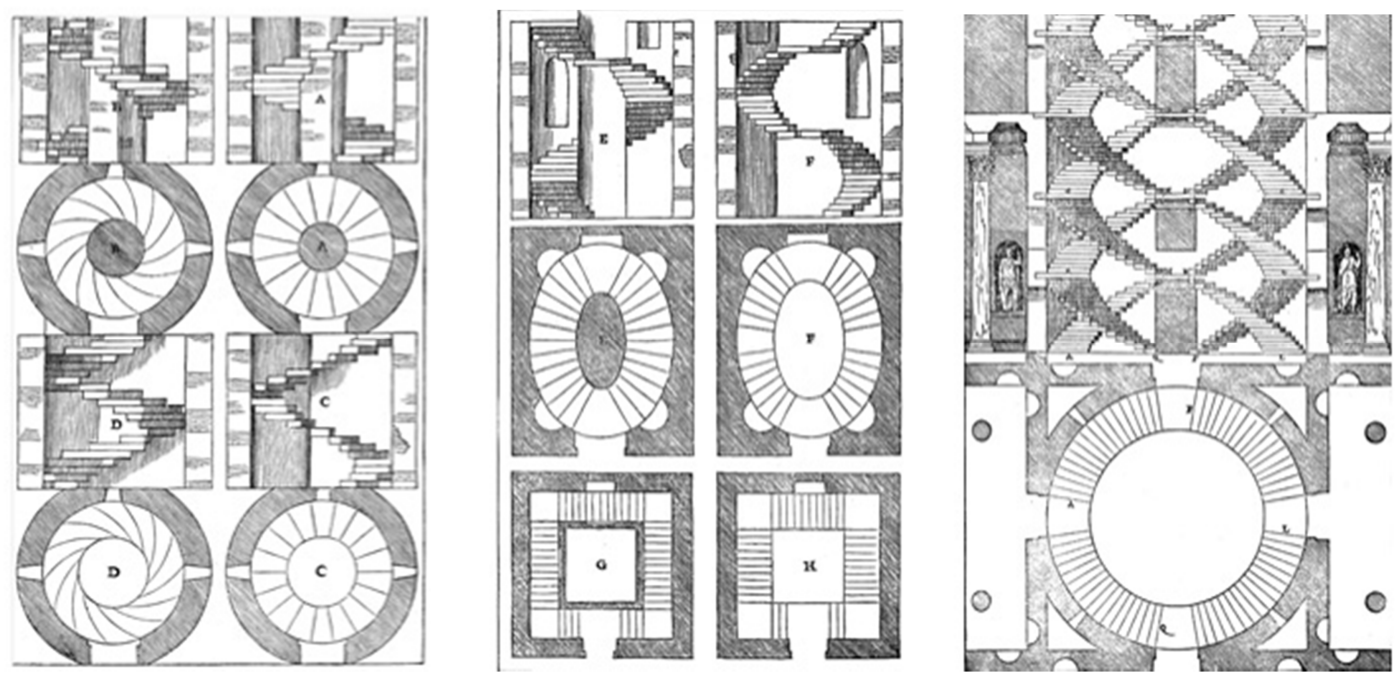

Fig. 6: Staircase construction with circular, oval, and elliptic forms. Right: Château de Chambord, France, the double helix of staircase. Source: [13].

Serlio was not the only one who analysed the potential of circular or oval forms, not only in the plans or shapes of the whole building. Andrea Palladio (1508 - 1580) mentioned in his I quattro libri dell'architettura (The Four Books of Architecture, 1570) examples of circular or oval staircases and also marvellous geometrical visual game of the double helix staircase form, Fig. 6.

Architectural forms, based on the oval and circular shapes, did appear from the 16th century, thanks to this books and treatises. Many of these forms were analysed in particular in [14]. Not only buildings, but the whole urban spaces were oval reshaped in renaissance and baroque urbanism. Examples are Michelangelo's Piazza del Campidoglio, Rome (1505) with finely calculated geometry up to Piazza di San Pietro - Square of the St. Peter in Rome (1656 - 1667) more detailed e.g. in [15].
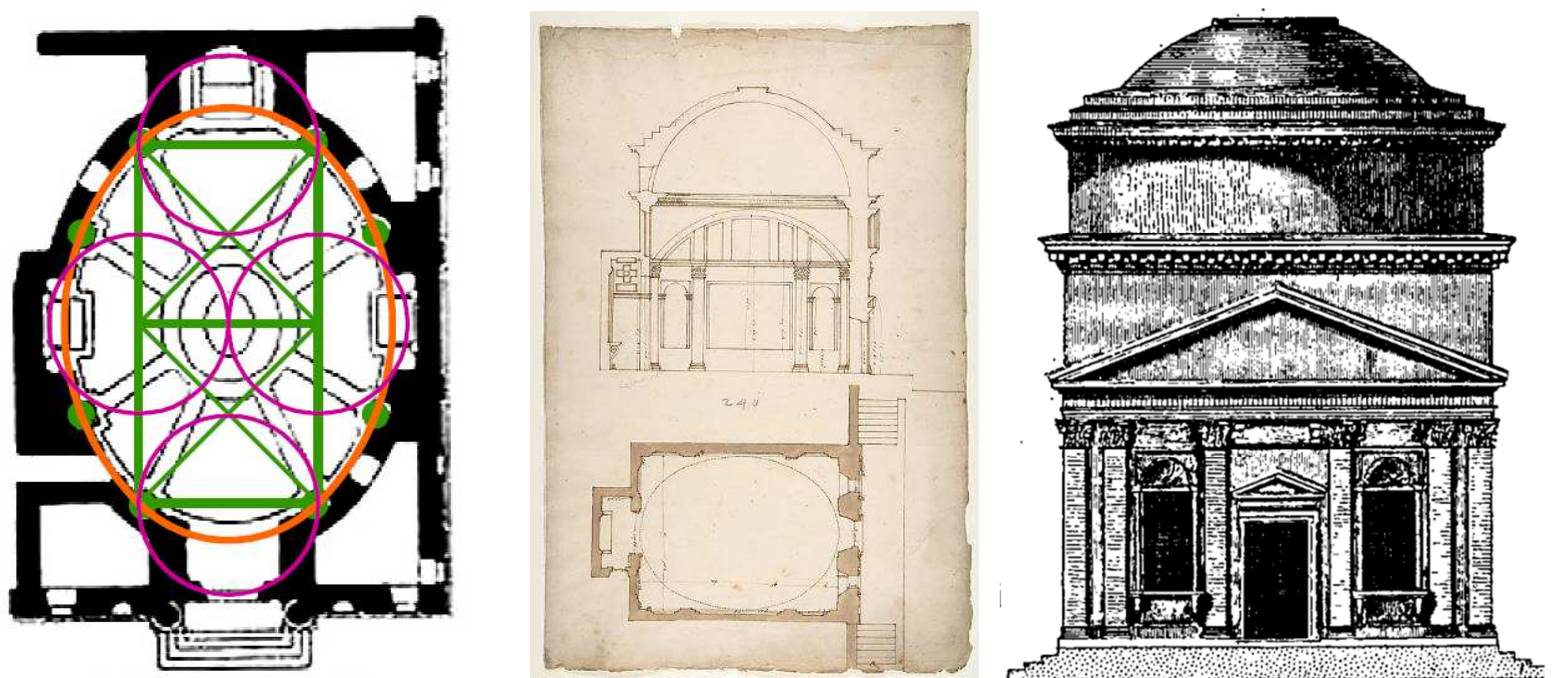

Fig. 7: Left: Giacomo B. da Vignola, Sant'Andrea in Via Flaminia (1552-1553) Drawing by Grúňová, 2016. In the middle and right: Sant' Anna dei Palafrenieri, 1565. Source: Wikimedia Commons.

Temples, considering only the most famous ones, were moving away from the relatively simple oval concepts of the Vignola's church of San Andrea (Giacomo Barozzi da Vignola, Sant'Andrea in Via Flaminia, built 1552 - 1553), Fig. 7, to the baroque games with the geometry of space. Here San Carlo alle Quattro Fontane by Francesco Borromini (1634), Fig. 8, could be mentioned. 


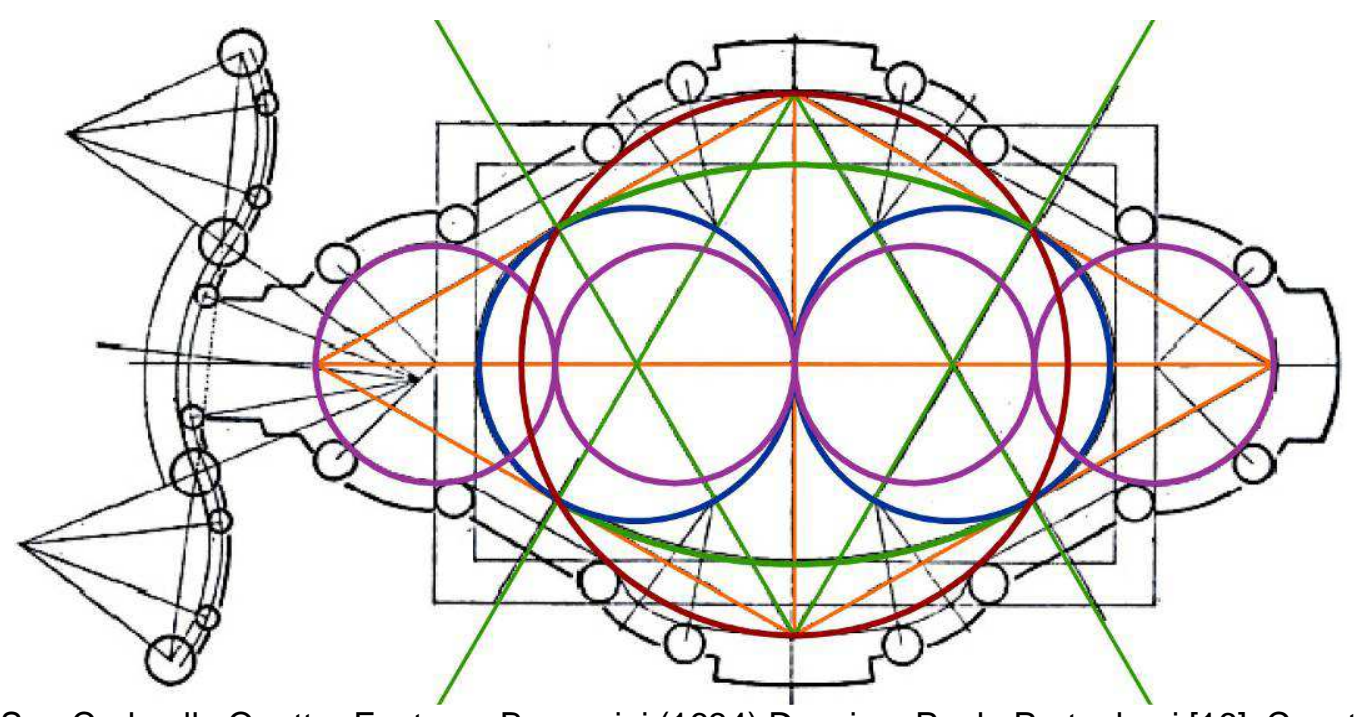

Fig. 8: San Carlo alle Quattro Fontane, Borromini (1634) Drawing: Paolo Portoghesi [16]. Construction added by Grúňová, 2016.

Vignola used oval also later in design of Sant' Anna dei Palafrenieri in Rome. It was the first time when the spaces were covered by elliptical/oval vault on a way to baroque works. Massive, cubic building has at the first glance certainly geometrically constructed proportions; rectangular plan seems to have $4: 5$ ratio (to be precise in the analysis reliable documentation have to be available). Building is in detail covered e.g. in [17].

Guarino Guarini was the one, who used geometry and mathematic reasoning in his work. He took also in consideration what could be called constructive geometry that means not only mathematical possibilities, but how to construct it simply on the building site. The geometric construction of a true ellipse and various kinds of ovals, reaching beyond Serlio's scope of constructions could be found in his treatises. All constructions are supplemented by connections to his proofs and discussion of Euclidus Elements. [18]

Other treatises, e.g. [19], about hundred years after Guarini's life and works already considered these constructions as common knowledge and used them to illustrate basic processes of geometric constructions for masons or stonemasons, e.g. how to divide voussoirs, Fig. 9.
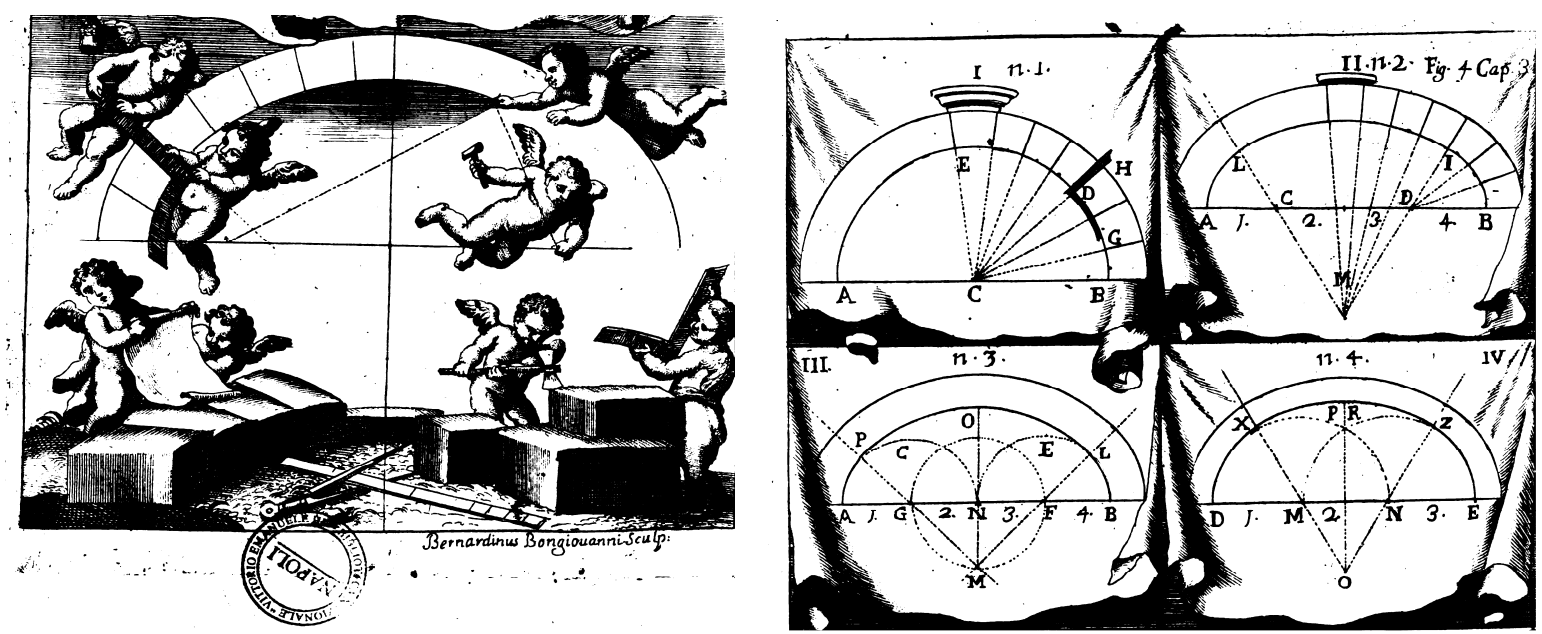

Fig. 9: Left: so called "gardener construction" of ellipse using two poles and rope. Right: methods of section of the arch - elliptic, oval or half circle - to voussoirs. Source of both: [19].

Not only Italian examples, architects of the many other nationalities used elliptical, oval shapes and curves, based on a complex intersections of the arcs in a dynamic baroque period of the world architecture: Church in Vierzehnheiligen (B. Neumann), Church of St. Charles Borromeo, Vienna (Karlskirche, J.B. Fischer von Erlach). Czech architecture boasted Dientzenhofers' and Hildebrandt's 
churches, amazing geometrical constructions were presented by so called Baroque Gothic by Jan Blažej Santini (e.g. Pilgrimage Church of St John of Nepomuk at Zelená Hora).

\section{Guarino Guarini's oval and elliptic constructions}

The exact construction of the ellipse could be found already in time of Serlio or Guarini Guarino $[12,18]$. They described it as we know it well even today. Circles with radii equal to the half lengths of the axes of the ellipse had to be constructed, denoted as $l(S, b)$ and the $v(S, a)$. The point $V$ was an arbitrary point of the circle $v$ and line $S V$ was drawn, intersecting circle $l$ at point $L$. Two lines, perpendicular to the axes of the ellipse $x$ and $y$ had to be drawn from points $V$ and $L$. Intersection of this two lines was the point $M$, the point of the ellipse. $M$ is really the point of the ellipse with axes lengths $2 a$ and $2 b$, what can be proved, e.g. by using affine properties of the ellipse. Using an analytical approach and a coordinate system as shown in Fig. 10, the circles have the parametric equations:

$v: x=a \cos t, \quad y=b \sin t, \quad l: \quad x=b \cos t, \quad y=b \sin t, \quad t \in\langle 0,2 \pi)$.

Point $M$ constructed as above has the coordinates $M[x=a \cos t, y=b \sin t]$ and it can be verified that it is really true that the sum the distances this point from the both focuses of the ellipse is $2 a$ and therefore $M$ is the point of the ellipse.

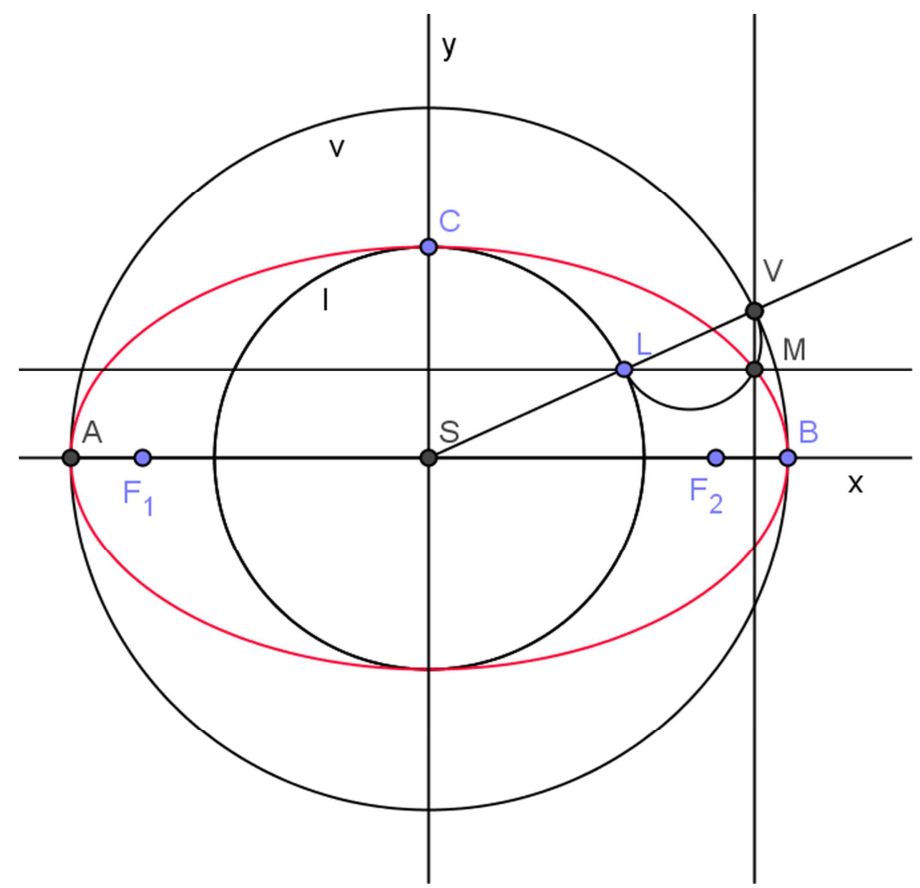

Fig. 10: Construction of "true" ellipse using two circles was known to Serlio and Guarini, but its properties are not so suitable for practical use in architecture and for construction at a building site.

However, construction of the ellipse was not used in architecture and in building practice exactly, approximation by ovals was more common. Architects were trying to compose ovals from the various numbers of the circular arches. It made sense to use in most cases only two different circle due to the symmetry of an ellipse. The constructs were based on the aesthetic necessity to find the centres and radius of the two circles that are connected smoothly. The circles had to have a common tangent in this point of connection, which meant that the centres $H, K$ (Fig. 11) of these circles had to lie on the same line. If it was considered $h=|S H|$ and $k=|S K|$, where $S$ was the centre of the oval. Found circles had radii of $a-h, a-h+\sqrt{h^{2}+k^{2}}$. 


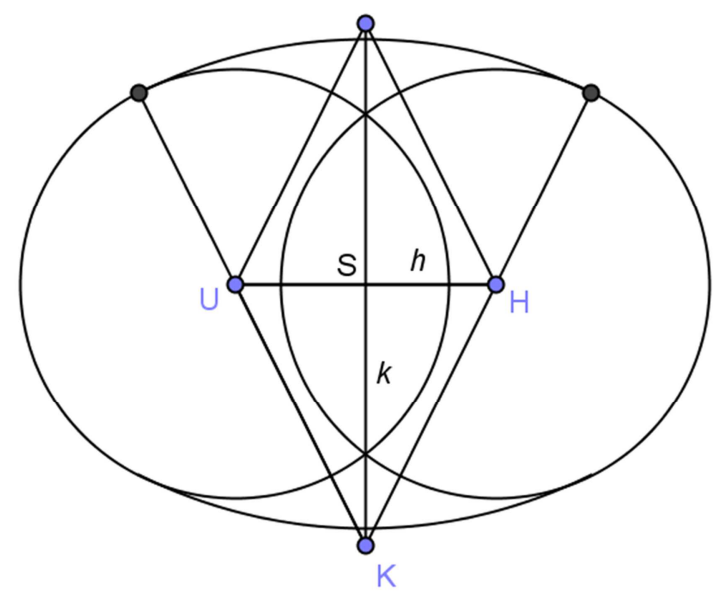

Fig. 11: Construction of two-centre oval, based upon Serlio's treatise.

In Serlio's constructions, $h$ a $k$ varied by the type of construction. UHK was the equilateral triangle in the case of construction Fig. 5a) and $h=(a-b) /(\sqrt{3}-1)$, $k=\sqrt{3} h$. The ratio of the radius of the circles and the ratio $a / b$ were not constant. These ratios are constant in other Serlio's construction, see [13]. In case Fig. 5 b) is $h=k=a /(\sqrt{2}+1)$, $a / b=(\sqrt{2}+1) /(2 \sqrt{2}-1)$ and the ratio of the radii of the arcs is $1 / 2$. In case Fig. $5 \mathrm{c})$ is $h=k=a / 2, a / b=\sqrt{2}$ and the ratio of the radii of the arcs is $\sqrt{2}-1$. In case Fig. $5 \mathrm{~d})$ is $h=a / 3, a / b=3 /(4-\sqrt{3}), k=\sqrt{3} h$ and the ratio of the radii of the arcs is $1 / 2$.

Guarini described construction to an oval generally, but he had chosen in [18] (Lastr. 3 Trat. 2., Fig. 7.) two circles with the same radius for the illustration. The two circles with centres $A$ and $F$, which have any distance, non-intersecting or intersect (each other), with equal or unequal radii could be taken, based on Guarini description. Non-intersecting circles with different radii were chosen as drawn in Fig. 12. Line $A F$ intersects this circles in points $I$ and $C$. Any length greater than half the line segment $\mathrm{Cl}$ was taken according to Guarini description and the points $G$ and $H$ were constructed, so that $|I O|$ equals $|C G|$ and is equal to this length. Circles with centres $A$ and $F$ and radii $A O, G F$ were drawn with common points - intersections $M$ and $H$. The line $M H$ is clearly perpendicular to the line $I C$. Lines $M F, H F, M A, H A$ could be drawn, intersecting circles at points $S, R$. (Fig. 12). The construction fulfils the aesthetic option of the smooth connection if the points $S$ and $R$ lie on a circle with centre $H$ and the radius $|S H|=|H R|$. But it must be proved if $|S H|=|H R|$.

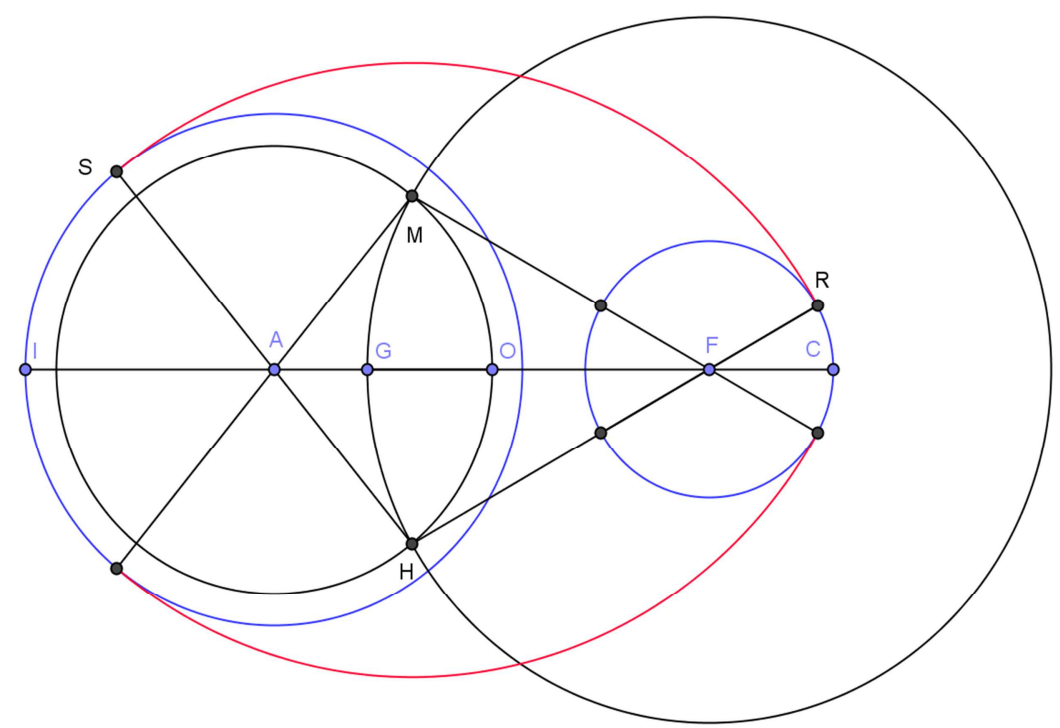

Fig. 12: Oval constructed using Guarini's method choosing two non-intersecting circles with different radii.

Manner of choosing the points $G$ and $O$ and the construction of point $M$ and $H$ determines that $|A O|=|A H|$ and $|F H|=|F G|$. Points $S$ and $/$ belong to the circle with centre $A$, hence is $|A l|=|S A|$. By analogy is true that $|F C|=|F R|$. The distance $|S H|$ and $|H R|$ could be expressed as: 
$|S H|=|S A|+|A H|=|A||+| A O|=| I O|| H R,|=| H F|+| F R|=| F G|+| F C|=| G C \mid$.

It is known that $|I O|=|C G|$, therefore $|S H|=|H R|$. If this is applied to the oval approximating an ellipse using the same circles, then points $C$ and $/$ determine the length of the major axis and the point $G$ determines size of the secondary axis. Guarini took non-intersecting circles and the point $G$ in which the chosen circle intersects the line $A F$. The appropriate choice of the characteristics of Guarini's oval could result in the Serlio's oval. Serlio's oval in the construction of Fig. $5 \mathrm{~d}$ ) could be taken as an example. In this case the radii of the circles had to be $2 a / 3$, the distance between centres of the circles had to be $2 a / 3$ and the point $G$ is identical to the point $A$.

Guarini's construction of Fig. 13 can be described also by means of algebra and certain conditions can be expressed.

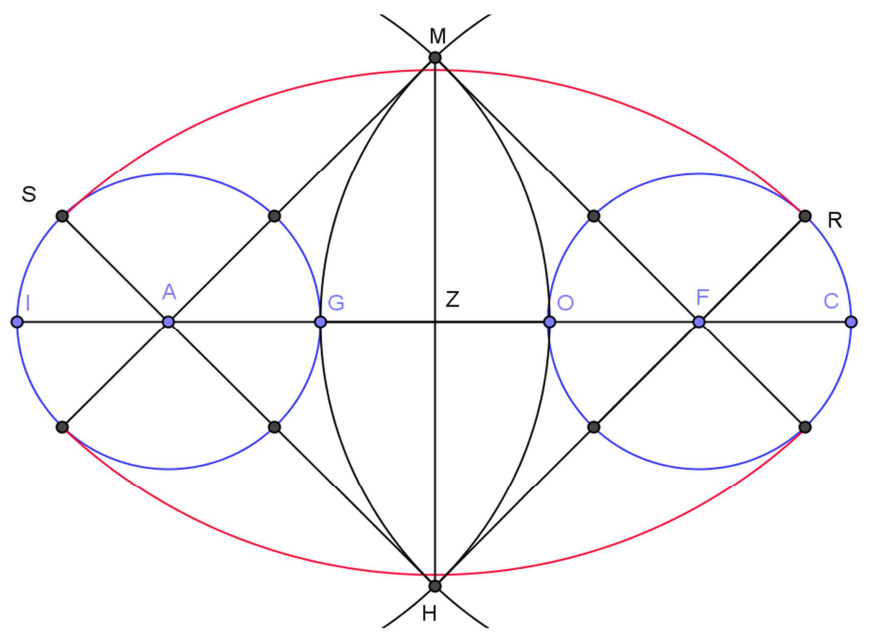

Fig. 13: Guarini's construction of oval, using a set of characteristics that would correspond to the Serlio's oval construction.

If $r=|A /|=|C F|$ and $h=\mid A F / 2$ are determined, the length of the major axis is $a=h+r$ with point $Z$ as the centre of the oval. It is clear that $|G O|=2(h-r)$ and $|G F|=|F H|=|G O|+r$. It follows that $|G F|=|F H|=2 h-r$ and the radius of the second circle which describes oval is $|H R|=|H F|+r=2 h$ $=\mid A F$. If $k=|Z H|$, can be algebraically expressed that $k=\sqrt{3 h^{2}-4 h r+r^{2}}$. The ratio of the radii of the arcs is then $2 h / r$ and ratio

$\frac{a}{b}=\frac{h+r}{2 h-\sqrt{3 h^{2}-4 h r+r^{2}}}$.

Guarini's construction has the architectonic advantage of possibility to choose aesthetically pleasing or otherwise suitable circle to approximate the corresponding ellipse in the main point. In the Serlio's process of Fig. 5a) this is it not possible. Disadvantage of Guarini's construction is that if it is demanded to obtain certain ratio of the major and minor axes of the oval/ellipse, it is no easy and clean way to geometrically construct point $G$ (determined by formula (3) that is rather difficult for building praxis).

\section{Baroque architecture in Slovakia based on oval and elliptic forms}

Baroque forms of architecture in Slovakia were an import of already well formed ideas, mainly brought by Jesuit order. Slovakia, as a part of kingdom of Hungary, experienced a long period of almost perpetual threat or warfare after battle of Mohács (1526) and following Turkish invasion into Europe that divided kingdom and ended its independency. Real expansion of baroque curves in details, plan and spirit of the buildings came in the period after the defeat of the Ottoman Empire expansion in Slovakia and after Anti-Habsburg rebellions in 1711 [19], until then warfare and uncertain conditions inhibited any bolder architectonic conceptions. Architecture of Slovakia has many examples 
of beautiful baroque architecture; this paper will mention mainly baroque and younger sacral buildings with central disposition, especially oval or elliptic ones.

Among those could be included monastery complex with Cathedral of St John of Matha in the centre of Bratislava (built 1717 - 1727) with illusive baroque painting by Galli Bibiena. Primaciálny palác (former palace, seat of Ostrihom archbishop) include chapel of St. Ladislav in its disposition plan. Chapel with oval/elliptical plan (authors have no precise documentation, suitable for verification) has a beautiful fresco painted on a vault by Franz Anton Maulbertsch in 1780, Fig. 15. Elliptic/oval disposition of a baroque church could be found also in Bratislava - Sts. Cosmas and Damian church in Bratislava's district Dúbravka. As an elliptical is often mentioned the St. Anne church of Ursulines order in Trnava, but this church is a central type, square one with concave curvilinear walls. Seems that at least Cathedral of St John of Matha in Bratislava can be described by one of the Serlio's ovals (Fig. 14), the authors have no precise plans at the present for any reliable analysis.
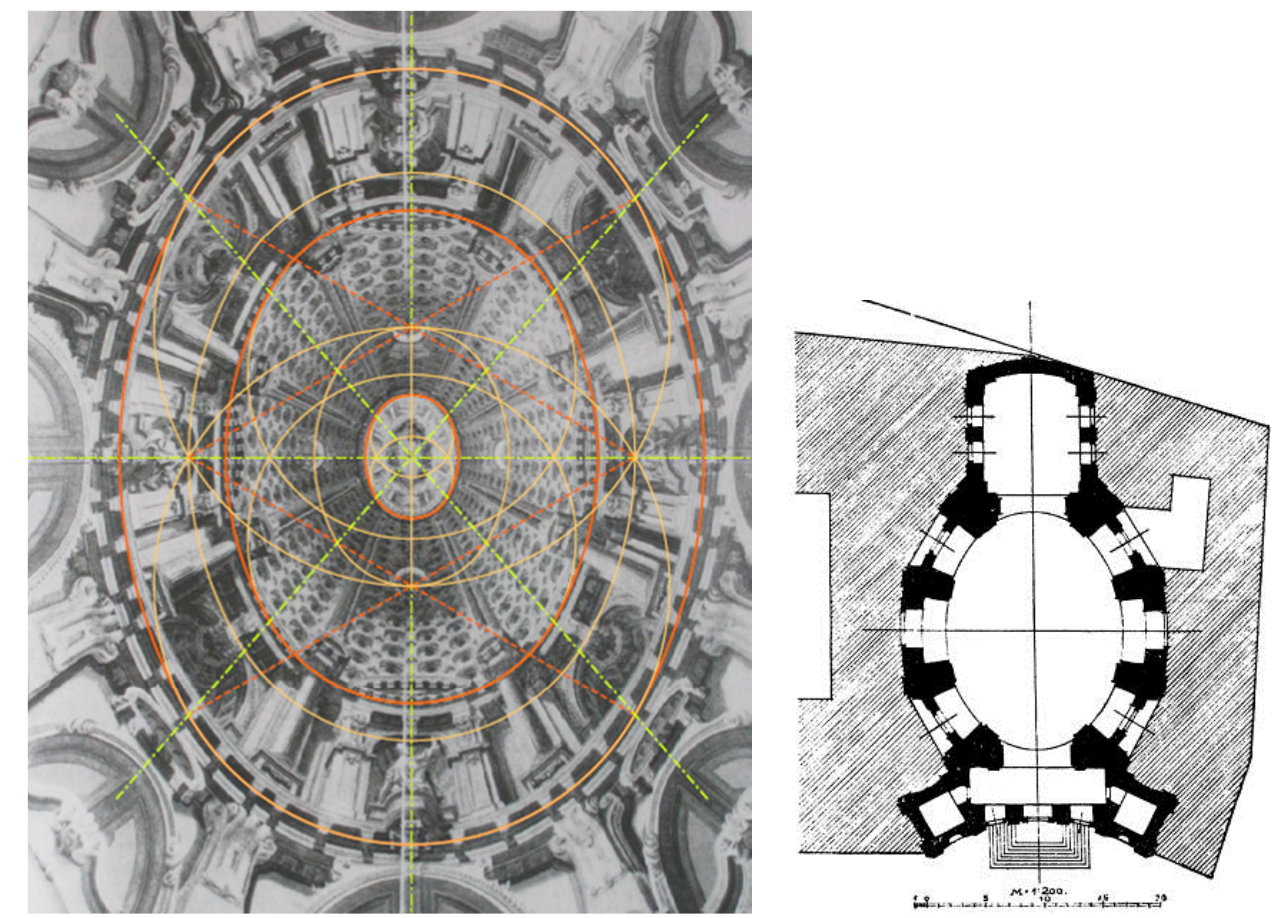

Fig. 14: Cathedral of St John of Matha in Bratislava (1717 - 1727), geometry of the vault and illusive fresco by Galli Bibiena. Drawing by Grúňová, 2016. Source: Wikimedia Commons.

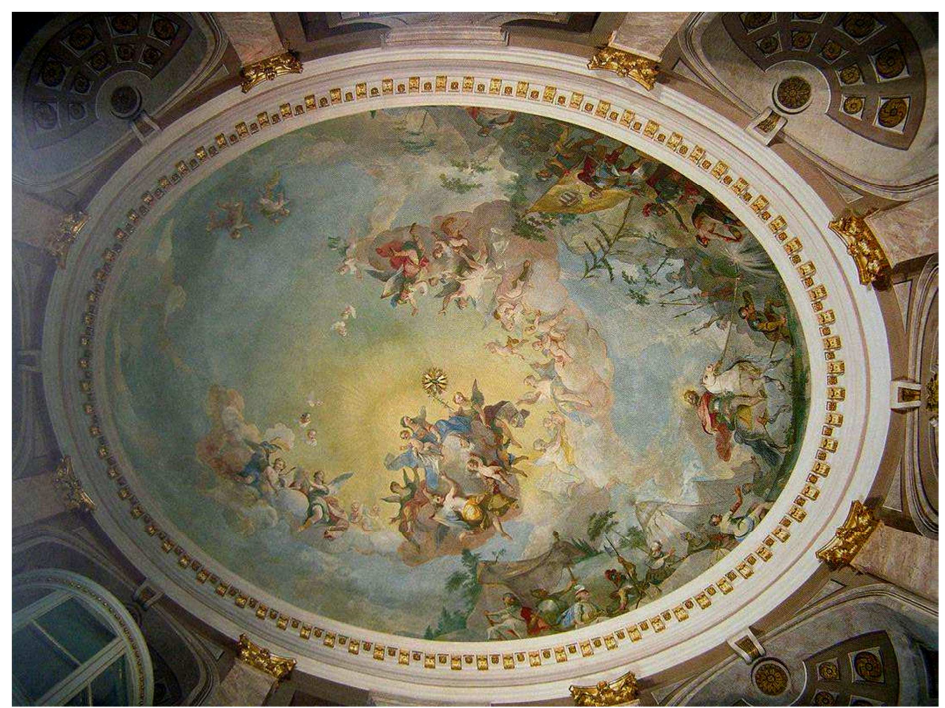

Fig. 15: Fresco vault painting in elliptic St Ladislav Chapel in the former Ostrihom archbishop's palace in Bratislava (Primaciálny palác). Source: Wikimedia Commons. 
More often are elliptical or oval plans used in architecture or interior elements of Evangelical temples, belonging to period of late baroque to neoclassicism. As examples could be mentioned evangelical temples in the rich mining towns of Kremnica, Banská Bystrica and Banská Štiavnica [20].

Temple in Banská Bystrica was built in 1803 - 1803 according to plans by Michal Pollack. Vaulted interior space has strictly speaking square disposition, but overall impact is more "rounded" because of in-built one storey high tribunes in circular shape. The same architect proposed plan of temple in Kremnica (built 1824 - 1826), here the load bearing walls create also circular plan. Evangelical temple in Banská Štiavnica was built in 1794, plans were by Vienna architect J. Thaller. Main temple space is elliptical with added lateral tribunes.

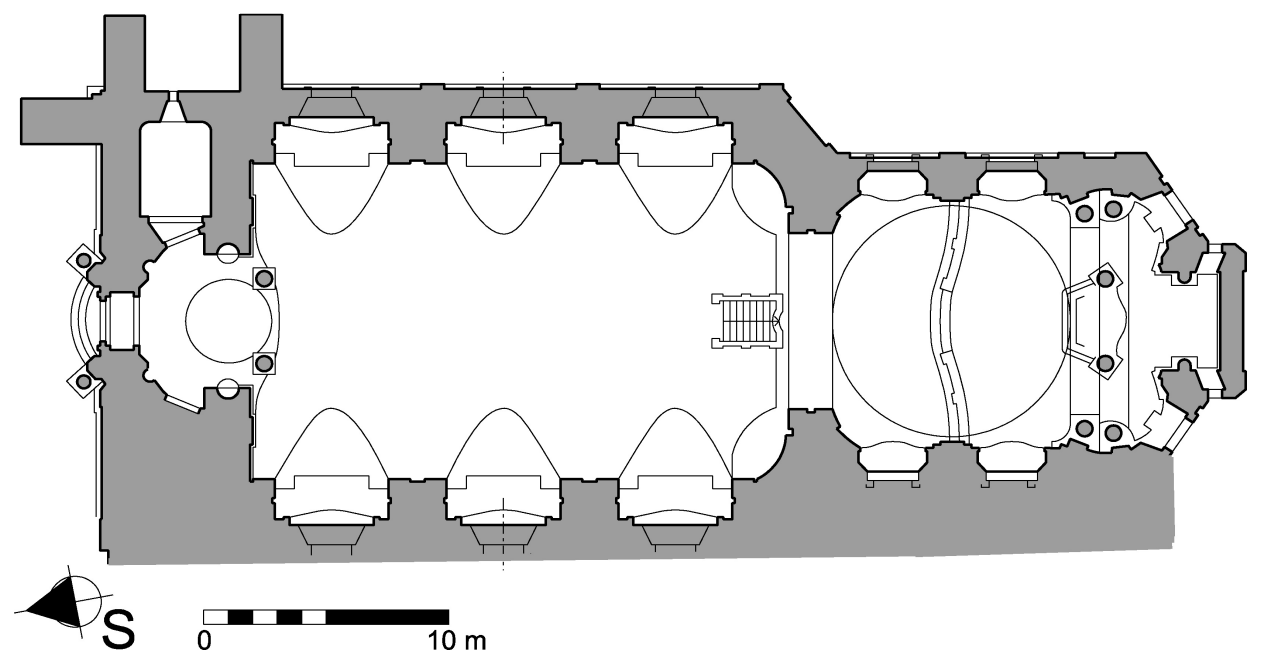

Fig. 16: The St Trinity church of Piarists Order in Prievidza (built 1666 - 1753). Drawing by Grúňová, 2016.

There are no artfully dynamically shaped spaces with complex geometry forms (additive, subtractive, distinctively curvilinear) in sacral architecture in Slovakia, which are known to authors. Many fine examples of illusive painting or / and stucco decorations etc. are based on the relatively simple disposition of rectangle or square with rounded corners or at least combined with circle. One of the most valuable baroque churches with illusive elements in Slovakia and Europe - The Trinity church of Piarists Order in Prievidza (built 1666 - 1753) with Dionýz Stanetti sculptures and paintings by Anton Schmidt and Ján Štefan Bopovský-Bujak from Vienna is skilfully crafted illusive space, but strictly geometrically speaking, almost all of it is the power of stucco, paint and perspective, curvilinear shaping of load bearing constructions is almost none, Fig. 16. Also no special form of plan or section of baroque building based on Guarini's construction where one of two circles is smaller was located in Slovakia. The geometrically simpler circle, easier for practical construction on the building site, it is much more often used in baroque or rococo architecture in Slovakia. Central, circular space is sometimes amended by additions - various antechambers, added square or rectangular sanctuary etc. Small chapels (baroque or younger) are also much more often circular, examples known to authors are: Modra, Chapel of Virgin Mary (1740 - 1760), Chapel of St. John Nepomuk on Pažica (the end of the 17th century), Calvary chapel in Bojnice (1816), Chapel of Saint Cross in Trnava's district Kompánka (1831), Calvary chapel in Bobrov, Orava region (1894). Evangelical temple in Zemianske Podhradie (built 1785-1801) has unique circular plan with surrounding arcade circle.

Elliptic and oval plans are more often used (but it is still rare occasion) in secular architecture of baroque, rococo or younger castels, palaces in Slovakia as in castel in Saca built by the Semsey family in 1776 with elliptical/oval main hall or almost forgotten elliptical/oval hall of smaller Summer Palace in Trnava on Vansovej street [21].

This article is a preliminary study of planned extensive research of curvilinear forms in historical central forms and spaces in Slovakia territory. Research will be aimed to establish rightful position of diverse, finely crafted and inventive architectural heritage in Slovakia in the historical evolution of the European architecture. 


\section{References}

[1] HUERTA FERNÁNDEZ, S.: Oval Domes: History, Geometry and Mechanics. IN: Nexus Network Journal, Oct. 2007. DOI: 10.1007/s00004-007-0040-3.

[2] ROSIN, P. L. - TRUCCO, E.: The amphitheatre construction problem, 2005. In: Incontro Internazionale di Studi Rileggere L'Antico, Rome, 13 - 15 December, 2004.

[3] TREVISAN, C.: Sullo schema geometrico costruttivo degli anfiteatri romani: gli esempi del Colosseo e dell'arena di Verona. Disegnare idee immagini n. 18/19, Anno X, Numero monografico, 2000. pp. 117 - 132 (in Italian).

[4] DUVERNOY, S.: Architecture and Mathematics in Roman Amphitheaters, pp. 81 - 93 in Nexus IV: Architecture and Mathematics, eds. Kim Williams and Jose Francisco Rodrigues, Fucecchio (Florence): Kim Williams Books, 2002.

[5] CALVO-LÓPEZ, J. - SALCEDO-GALERA, M.: Geometrical Proportion in the Sixteenth Century: Methods and Constraints. Nexus Network Journal (2017). DOI 10.1007/s00004-017-0329-9. Online: http://rd.springer.com/article/10.1007/s00004-017-0329-9.

[6] CHAPPUIS, R.: Utilisation du tracé ovale dans l'architecture des églises romanes. In: Bulletin Monumental, tome 134, $n^{\circ} 1$, année 1976. pp. 7 - 36. DOI : 10.3406/bulmo.1976.2658. Online: http://www.persee.fr/doc/bulmo_0007-473x_1976_num_134_1_2658 (in French).

[7] EUCLID: Preclarissimus liber elementorum Euclidis perspicacissimi: in artem geometrie incipit qua[m] foelicissime. Venice, 1482. The first printed edition of Euclid's Elements. Issued in Venice in 1482 by the German printer Erhard Ratdolt, it is also thought to be the first book with a known date of publication to contain printed diagrams, hundreds of which are used to illustrate Euclid's theorems. Online: https://archive.org/stream/preclarissimusli00eucl\#page/n159/mode/2up.

[8] HEIBERG, J. L.: Euclid. Euclidis Elementa. Leipzig. Teubner. 1883 - 1888. English version, available as a Perseus library open source text. Online: http://www.perseus.tufts.edu/hopper/ text?doc=Perseus\%3Atext\%3A1999.01.0086\%3Abook\%3D2\%3Atype\%3DProp.

[9] TODOROVA, R.: The migrating symbol: Vesica piscis from the Pythagoreans to the Christinanity. In: Proceedings of the 1st International Conference „HARMONY OF NATURE AND SPIRITUALITY IN STONE“, held on 17 - 18 March 2011 in Kragujevac, Serbia, pp. 217 - 228.

[10] TODOROVA, R.: The Aureole and the Mandorla: Aspects of the Symbol of the Sacral from Ancient Cultures to Christianity. In: STUDIA ACADEMICA ŠUMENENSIA, 3, 2016, Shumen University Press. pp. 199 - 223.

[11] WITTKOWER, R.: Architectural Principles in the Age of Humanism. John Wiley and Son, 1998.

[12] SERLIO, S.: II primo [-secondo] libro d'architettura. Venice, 1545. Online: https://archive.org/ details/gri_33125008448702, (in Italian).

[13] ROSIN, P. L.: On Serlio's constructions of ovals. IN: The Mathematical Intelligencer, 23 (1) : 58 - 69, 2001. DOI: 10.1007/BF03024523.

[14] KITAO, T., K.: Circle and Oval in the Square of Saint Peter's. Bernini's Art of Planning. New York, New York University Press, 1974.

[15] FALCOLINI, C. - VALLICELLI, M. A.: Modelling the vault of San Carlo Alle Quatro Fontane. In: Aplimat - Journal of Applied Mathematics. Vol. IV, 2011, No. IV., p. 144.

[16] LEWINE, M., J.: Vignola's Church of Sant'Anna de' Palafrenieri in Rome. In: The Art Bulletin. Volume 47, 1965, Issue 2. pp. 199 - 209.

[17] GUARINI, G., 1624-1683; GUJENOTTI, F., fl. 1686 - 1693; ABBIATI, G., fl. 1678 - 1700; FAYNEAU, G., fl. 1686. Architettura civile: opera postuma. Published in 1737. Online: https://archive.org/ details/gri_33125008641249. Trattato II. Cap. VI. Osservazione Settima Dell' Ovato fatto con piu porzioni di circolo. (Lastr. 3 Trat. 2. Fig. 7.) Trattato II. Cap. VI. Osservazione ottava. Del modo di formare una Elisse, od Ovato con due centri. (Lastr. 3 Trat. 2. Fig. 8., Fig. 9.) (in Italian).

[18] AMICO, Giovanni, B.: L'Architetto Prattico : in cui con facilta si danno le regole per apprendere I'Architettura Civile, e Militare. Palermo, 1726. Parte I. Capo VI. Dell'Achitettura Civile. Fig.3, Fig.4. Online: https://archive.org/details/larchitettopratt02amic (in Italian).

[19] KIBIC, K. - MAZLÍK, D.: Vývoj architektúry v renesancii a baroku. Alfa, 1992. ISBN 8005010249 , 9788005010248 (in Slovak)

[20] LUKÁČOVÁ, E. - POHANIČOVÁ, J.: The diverse 19th century. Architecture of Slovakia from Hefele to Jurkovič. Perfekt, Bratislava, 2008. 246 pages. ISBN 978-80-8046-426-4 (in Slovak).

[21] Summer palace, street of Terézia Vansová in Trnava. Architectonic - historical research on cultural monument by Jaroslava Žuffová, Mária Smoláková, Peter Buday, Daniela Zacharová. 2014. Original of documentation is archived at the Board for Monument Preservation in Trnava. (in Slovak). 